\title{
The Namesake in Persian
}

\section{An on-line translation workshop}

\author{
Esmaeil Haddadian Moghaddam \\ International Studies Group, Universitat Rovira i Virgili, \\ Tarragona, Spain
}

\section{Introduction}

Translation, and literary translation in particular, is no longer a static activity. By "static" here, I mean the translator's absence from the realm of the readership in the process of the translation. As Frank Austermühl rightly pinpoints in his book, Electronic Tools for Translators, one of the few reference books on recent innovations in translation and on electronic tools for translators, "the antiquated image of a lone translator, armed only with a pencil or typewriter and surrounded by dusty books, is no longer realistic" (1). Thanks to recent developments in communication technologies, and the Internet in particular, the process of translation, the very definition of translation, the work and the function of the translator, have undergone revolutionary transformation. According to Jeremy Munday, the Internet is "changing the status and visibility of translators and translations. Not only can professionals now easily work transnational via email, but the need for translation itself is also changing" (191). Consequently, the majority of translators are working in a global network equipped with better communication and financial opportunities.

In the process of translation, a number of recent changes have taken place and new tools for translators and their readers have been introduced. As much as translation is "available at the touch of a button for Internet users worldwide" (Munday 191), translation tools are also easily accessible. The translation tools here refer to those facilities "designed to facilitate human translation through providing a terminology management system, instant access to on-line dictionaries, and other utilities" (Newton 2). Depending on the type of the translation, these tools should be selected carefully and examined before the application.

In addition to the services provided by machine translation, terminology databases, on-line dictionaries and libraries, there is a very popular electronic phenomenon in the cyber world called web log. The web log is a "web page that serves as a publicly accessible personal journal for an individual" (Wikipedia). The

Babel 54: 2 (2008), 125-144. C Fédération des Traducteurs (FIT) Revue Babel DOI 10.1075/babel.54.2.03had ISSN 0521-9744 E-ISSN 1569-9668 
web log has been neglected in translation studies, partly because of its novelty, but mostly because of its popularity as a platform or a personal diary for the novice bloggers, the authors of the web logs.

Because of the increasing importance of web logs ${ }^{1}$ during the last few years, there has been more attention to the web logs recently. Unfortunately, the translators and translation theorists and the teachers of translation have not given it a warm welcome. One purpose of this paper is to pinpoint the covert value of web $\log$ in the translation process, and in literary translation in particular, in light of the application of the web log as an on-line translation workshop. Another purpose is to examine its effects with respect to the Persian translation of The Namesake. I will argue that "the right tools" of translation, in this case web logs or personal web pages of the translators, "can help good translators improve the efficiency and quality" of their translations (Austermühl 1) and finally to produce a good translation that is acceptable in the target language. However, producing a good translation depends on other qualities like the translator's thorough knowledge of source and target languages, familiarity with both source and target cultures, and long years of translation experience. In this article, it is assumed that our translator has already obtained these qualities.

In the present literature on electronic tools for translation and translators (see Austermühl; Posteguillo et al.; Newton) nothing has been said about the use of web logs or a translator's personal web page as a platform or an on-line workshop for translation. Although no reference has been made to the application of the web log in translation as I already mentioned, some associated concepts have been introduced that are inevitable and advantageous at present and in any other discussion of the issue.

As much of an on-line translation workshop happens in a cyber world, and all the participants use the Internet in their activities, it is obvious that they are involving in a different interaction with literature and reading. Maria Goicoecha in her article, "Reading Cyborgs" (in Posteguillo et al. 73), sheds some light on the development of the concepts of "digital literature" and "interactive reading". She sees "the contemporary reader" as one who "has become familiarized with reading on screen". By "cyborgs" she means those texts that "can interactively communicate with the reader" (74), as opposed to traditional texts, where no communication is possible between the writer and the reader. This unique feature of interactivity is one that can be fully employed by literary translators who see web logs as a tool in their translation and wish to benefit from interaction with the readers, their future potential readers of the printed translation.

1. See for example: Macintyre, Ben. 


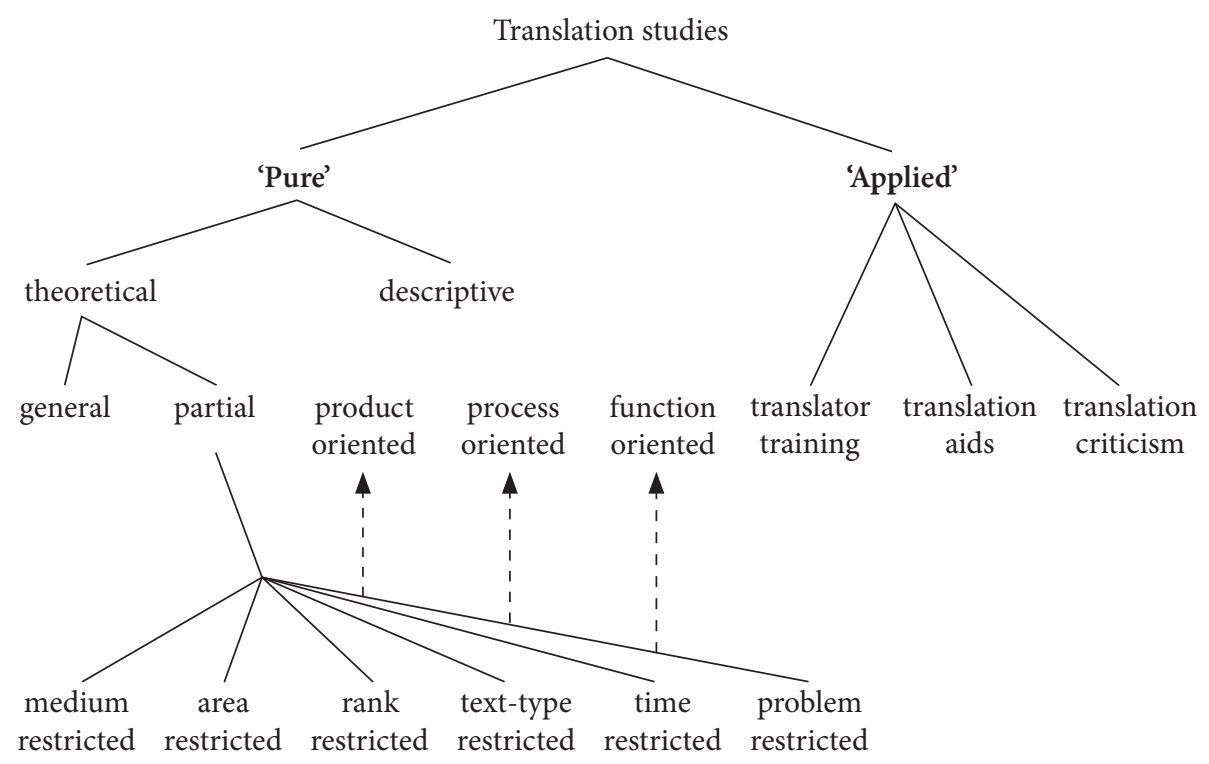

Figure 1. The Holmes-Toury map of translation studies (Munday 10)

Despite the fact that the history of translation goes back as far as the tower of Babel $^{2}$ (Genesis 11:9), (see for example the entry of Tower of Babel, Douglas Robinson, in Baker 21-22), translation studies is a young discipline indeed; and as Venuti suggests, it has flourished practically in "the past thirty years" (1). Translation theorists have proposed different definitions and categorizations of translation studies. The one I would like to employ here was suggested by Baker. She argues that translation studies is an "academic discipline concerned with the study of translation at large, various forms of oral interpreting, as well as dubbing and subtitling" (277). She later expands it by putting "the whole spectrum of research and pedagogical activities, from developing theoretical frameworks to conducting individual case studies to engaging in practical matters such as training translators and developing criteria for translation assessment" (277) in her definition. ${ }^{3}$

In an effort to incorporate the web $\log$ in the present models of translation studies, it is necessary to review briefly one of the present models. The HolmesToury map of translation studies (Munday 10) provides the primary framework for any kind of study within the field of translation (Fig.1). Munday expands the righthand side of the map (the applied branch of translation studies) by subdividing

2. See for example: Robinson, Douglas in Baker (2001).

3. For a brief introduction to translation studies, see Munday 5-6. 


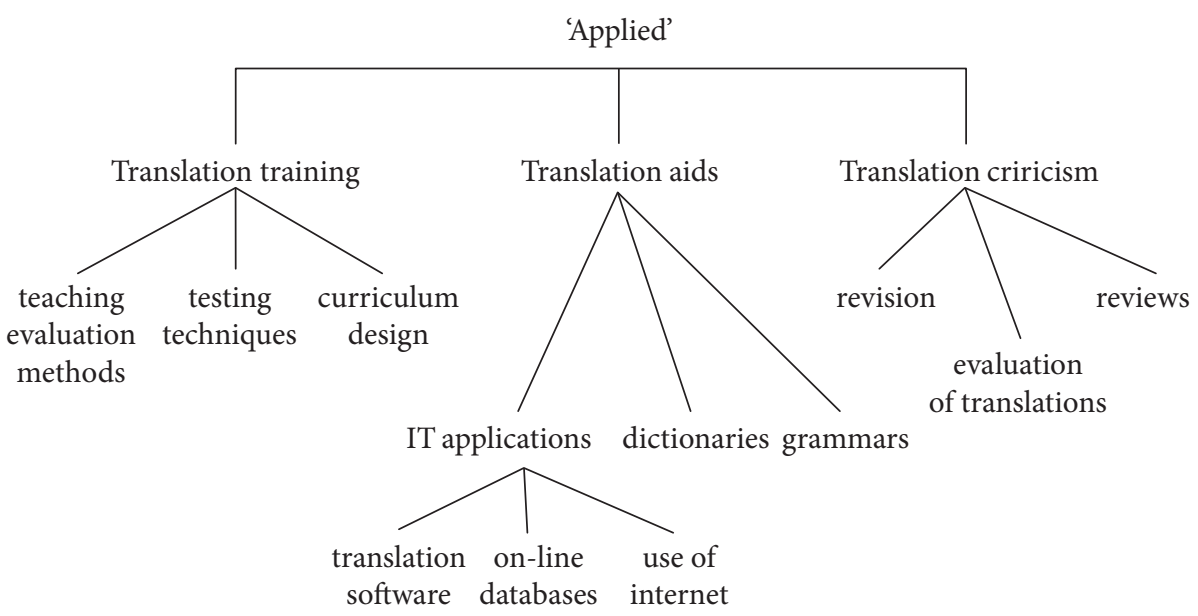

Figure 2. The expanded applied branch of translation studies (Munday 13)

each of them, believing that this "division is nevertheless flexible enough to incorporate development such as technological advances of recent years...." (Fig. 2).

By expanding the branch of the "use of Internet" in Figure 2, there is now a place for any discussion of web logs in translation. However, I would like to present another aspect of the application of the Internet in translation. Heather Fulford and Joaquin Granell Zafra in their review of the principal Internet resources currently available for translators (Fig. 3), one of the practical articles on hand for the use of translators, present a two-part categorization of Internet based resources for the translators (qtd. in Posteguillo, Santiago et al. 223-239).

\begin{tabular}{|l|l|}
\hline Resources designed for translators & General purpose resources \\
\hline Finding terminological or linguistic data & $\begin{array}{l}\text { Finding background (subject-knowledge) } \\
\text { information }\end{array}$ \\
\hline Communicating with fellow translators & Accessing bibliographical information \\
\hline $\begin{array}{l}\text { Producing draft / information-only } \\
\text { translations }\end{array}$ & $\begin{array}{l}\text { Accessing information from subject-field } \\
\text { specialists }\end{array}$ \\
\hline
\end{tabular}

Figure 3. Internet resources for translators

In this categorization and on the left side of the table, the subcategory of "communicating with fellow translators", there is an indication of a feature that can

4. For more information see Toury 9-10; and "The name and nature of translation studies" in Venuti (ed.), 172-185. 
be attributed to the web logs also. Although they never refer to web logs in their article, they can be used efficiently due to their interactivity characteristics.

Heather discusses the different resources illustrated in Figure 3 in detail, and under the third subdivision in the right side of the table, incorporates three more subdivisions that of "direct communication, mailing lists and language professionals/specialists gateways"(235). Subdivided in "direct communication" is the application of homepages (www), which best serves our purpose in this paper. Consequently, whether we apply Fullford's "two part categorization of Internet-based resources" or Munday's developed model of Holmes' map of translation studies, we have a good point of departure to examine the application of the web log in the process of the Persian translation of Jhumpa Lahiri's The Namesake.

\section{The web logs and The Namesake in Persian}

\section{The web logs}

With the appearance of web logs as a personal medium in the cyber world which demands no particular technical knowledge of the computer, except access to the internet, the publishing and sharing of ideas have become much easier in comparison to the last ten years. Web logs, or briefly, blogs, are easily accessible, cheap and "open up a vast marketplace of ideas" (Macintyre 2004). Everyone who has basic knowledge of computers and information technology and has something to say and share with others can use web logs.

Technorati, a website that claims to be the authority on what is going on the world of the web logs, is now tracking 19.6 million web logs as of October 2005 in the blogosphere", and claims that "the blogosphere has doubled at least five times in the last years", and on average, "between 700,000 and 1.3 million posts are made everyday" (Technorati). Of course not all these posts are of the same value, as many of them are just personal and receive a limited number of visitors (Fig. 4).

In Iran, web logs are more or less politically oriented; viewed as a mouthpiece for dissidents who do not find any official medium in which to express themselves. The phenomenon of web logging in Iran has been of such significance that recently a book called We Are Iran: the Persian Blogs was published by Nasrin Alavi, in which she claims that "Farsi [Persian] is the fourth most frequently used language for keeping on-line journals" (2). It seems that Iranian bloggers are working hard to improve their ranking despite the recent official crackdowns on the use of the internet in Iran.

5. The collective term encompassing all web logs or blogs as a community or social network (Wikipedia). 


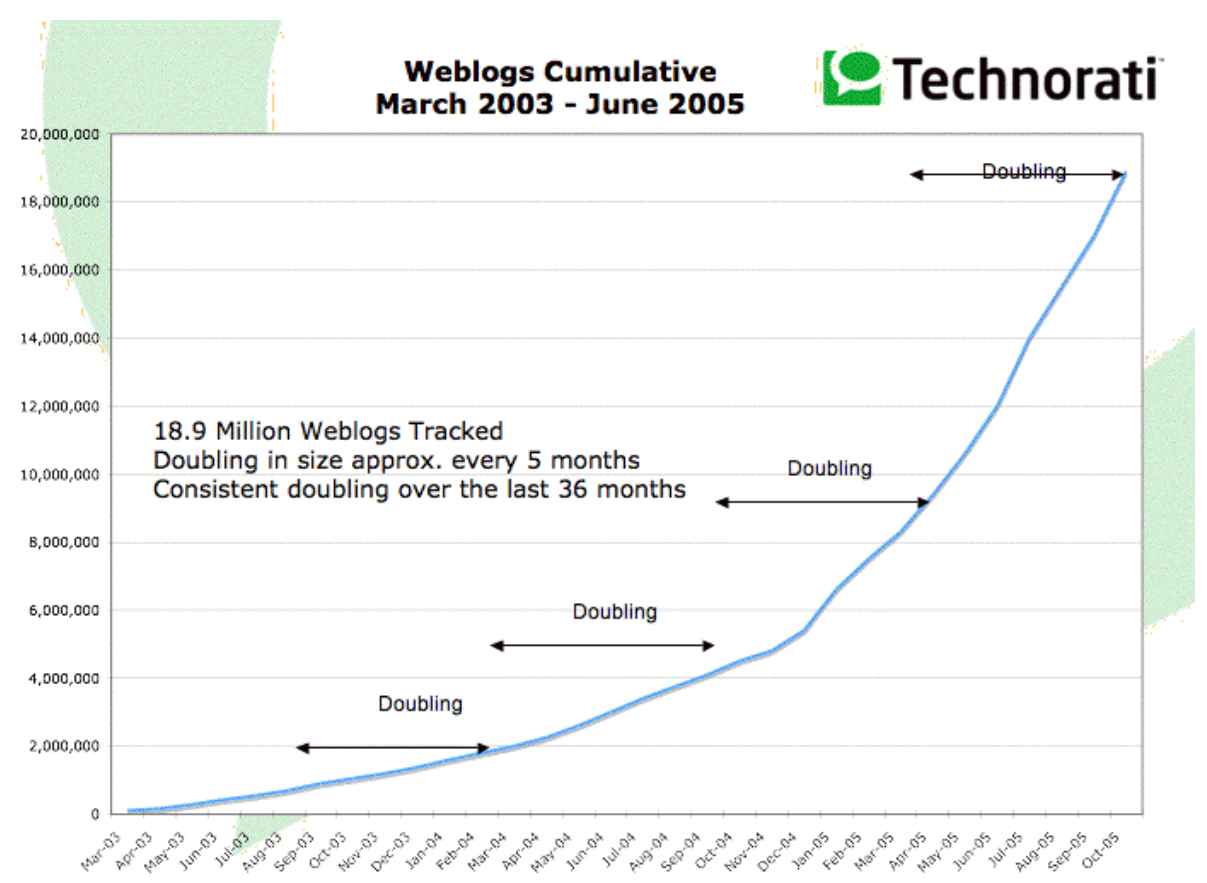

Figure 4. Web log Cumulative, March 2003-June 2005 (Technorati.com)

However, not all the Iranian web logs are political. ${ }^{6}$ According to Persianblog, a Persian blog service provider, which has more than 500000 users, there are currently 5962 blogs on literature and 2008 under the general category of writing. It is quite interesting to know that some of these web logs are written by Persian translators.

As a translator and blogger myself, I created my own web log, Translation and Intercultural Studies, in September 2002, one of the first web logs on translation in Iran. It was intended to be a platform for sharing my ideas as a translator on translation, and providing an on-line resource for Iranian translators and university students of translation. There are now around twenty web logs and websites on translation and translation studies in Iran; some of them are written by professional translators and translation teachers in Iranian universities.

Tarjomeh (translation) is the name of a web log by Amir Mehdi Haghighat, a young Iranian literary translator, whose Persian translation of Jhumpa Lahiri's The Namesake is the main impetus for writing this article. He has already published a Persian translation of Lahiri's short story collection, The Interpreter of

6. See for example: Haddadian Moghaddam. 
Maladies. But before close analysis of his translation of The Namesake and his online translation workshop of this novel, it is better to look at The Namesake and Jhumpa Lahiri's popularity in Iran.

With the publication of the Persian translation of The Interpreter of Maladies, the Pulitzer prize winner in 2000, Iranian readers found a new voice in contemporary American writers, a voice rooted in an immigrant background. As a large number of Iranians live in the United States, and immigration forms a part of Iranian identity, and the book was written on the problems of an Indian family in the United States, it gained unprecedented popularity in Iran. Lahiri writes a "beautifully controlled prose. She resorts to unusual word choices only when she needs them to fix an important moment in the reader's mind" (Kipen 2003). Apart from these reasons, Lahiri's stories are written with careful narration, elegant description, and sympathetic compassion.

Following the successful publication of Lahiri's first book in Iran, Iranian readers waited impatiently for another Persian translation of her books. With the publication of The Namesake, a novel about "an immigrant family's imperfect assimilation into America" (Kipen 2003), the Iranian translators' competition to produce the first Persian translation of this book was already at high peak. Haghighat was also among them, but he decided to inform others of his decision, hoping that this initiative would entice other translators not to produce repetitive translations. However, two Persian translations of this novel appeared before Haghighat's. ${ }^{7}$

\section{Haghighat's web log as an on-line translation workshop}

Haghighat started his web log, Tarjomeh, as a "platform to talk about the pleasures of translation and the creative Persian equivalents for the English words and expressions." In his first post to this web log, he wrote: ${ }^{8}$

I am not going to write in detail here in this web log; instead, it is intended to be useful and brief. I have found very good equivalents and probably a couple of elegant and clear equivalents for the English complex sentences. It is believed that my visitors will observe and learn something from them.

His visitors were expected to be among the translators, translation fans, young and novice translators, and even veteran translators who might feel posting their

7. Gita Garakaani, Tehran: Elm Publication 1383; and Farideh Ashrafi, Tehran: Morvarid Publication, 1383.There has not been any comparison between these three translations so far.

8. It should be noted that all the quotations from this web log are my English translations. 
experiences in translation would help young translators to find their own path in the world of translation.

In the process of writing this article, and upon closer scrutiny, establishing contacts with Haghighat, I came across some important facts that should be kept in mind. First of all, almost all the posts related to the Persian translation of The Namesake were sent to the Tarjomeh web log while the translation manuscript was already under the publication process. ${ }^{9}$ It was actually in the Auditing Office of the Ministry of the Islamic Culture and Guidance, or as Haghighat told me via email, "the censorship ministry", where all prospective books to be published are required to be monitored closely and receive the publication permission. Therefore, while the Persian translation of The Namesake was in the process of publication, Haghighat kept posting to his web log about his translation, received the visitors' comments, used some of the proposed Persian equivalents in his final draft and established the first on-line translation workshop. Secondly, though the Tarjomeh was created to be a platform for discussion on translation, it received different feedbacks from visitors; within and outside the topic of translation. I will later distinguish between these posts and review each of them separately.

Before analyzing the on-line workshop of The Namesake, a few words on the concept of the translation workshop is needed. The theory and practice of the translation workshop in the United States mostly known as the North American Translation Workshop, have been viewed as a platform for creative writing; (see Gentzler 5-43), and Munday believes that it favors "unity, cohesion, similarity, fluency, and acceptability" (39) of the proposed translation. On the contrary, the translation workshop outside the United States has been more or less practiced in its literal meaning. An ordinary translation workshop is one in which a translator teacher, sometimes with a professional translator, divides the students of translation into small groups of four or five people and gives them the same source text to translate into their mother language or target language. The teacher and the professional translator take part in the process of translation and help the translation students to produce a translation that is faithful and acceptable.

In the study of the web $\log$ as an on-line translation workshop, the translator substitutes for the teacher and the web log visitors play the role of the translation students. The interaction of the translator and the web log visitors is through the posts the translator makes and the comments the visitors send by using different services that are available for commenting in a web log. What distinguishes the online translation workshop from its traditional one is its round-the-clock opening, facilitated interaction with the translator, absence of any formal setting and formality and instant access to available sources in the internet.

9. The publication process in Iran is a different and lengthy process. 
Austermühl believes that mailing lists or discussion groups are "an efficient way to contact experts in various fields or to get help with terminology issues" (41). Wakabayshi also argues that these mailing lists are "an increasingly powerful force in the skill-building and professional socialization of translators" (in Hung, 48-58). Essentially there are some similarities and differences between the online translation workshop and translation mailing lists or translation discussion groups. Though in the latter, the members can send messages to the group, each member receives a copy of each post and receive all the other posts sent by other members, there is a high degree of spam receiving, in the form of electronic junk mail or junk newsgroup postings. However, in the web log, there is no subscription required as in the mailing lists; consequently, the possibilities of receiving spam is low due to the technical setting; and as the discussions are more focused on a single subject, the literary translation, the effectiveness and productivity of the translation discussions are more evident.

\section{Analysis of the Tarjomeh on-line workshop}

Having discussed the general issues so far, it is now time to examine the on-line translation workshop of The Namesake in detail. In doing so, I will provide some examples of the web log by dividing them into two categories of equivalents and general discussions. As a result of this categorization, we will have a better understanding of the workshop and the issues it covered.

\section{Equivalents}

In this part, I will present five examples of the workshop: first of all, the Persian discussions, and then the English translations. The translator's discussion comes first.

\section{1}

Alka seltzer

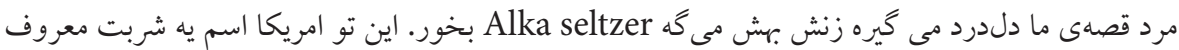

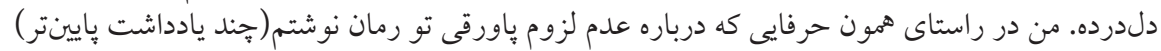

$$
\begin{aligned}
& \text { نو شتم شربت معده بخور. }
\end{aligned}
$$

(marde qeșe mā del dard migire, zanesh behesh mige alka seltzer bekhur. In tū āmrika esme ye sharbateh mảrūfe del dardeh. Man dar rastaye hamūn harfhāīe ke darbare 'adame lozūme pavaraqi tū romān neveshtam (chand yaddasht paīen tar), neveshtam sharbate me'de bekhur.) 
Shohreh

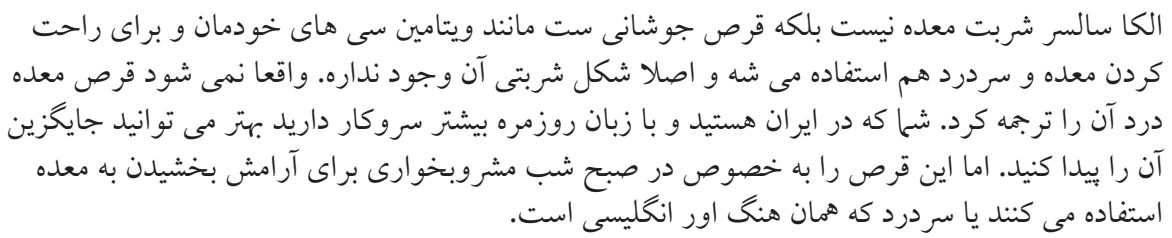

(elka seltzer sharbate me'de nist balke qorṣe jūshānist manande vitamin cihaye khvūdeman va barāye rāhat kardane me'de va sardard ham estefadeh mishe va aslan shekle sharbati ān vūjūd nadareh. Vaqean nemishavad qorṣe méde dard ān rā tarjomeh kard. Shoma keh dar iran hastid va bā zabāne rozmarreh bishtar sarū kar darid behtar mitavānid jaygozine ān rā peydā konid. Ammā in qorṣ ra be khūsūs dar șobhe mashrūb khvāry baraye ārāmesh bakhshidan beh me'de estefade mikonand ya sar dard keh hamān hang overe engelisi ast.)

In a part of the novel, one of the characters suffers from a stomach ache. He is advised by his wife to take some Alka Seltzer. Haghighat writes in his web log: "Alka Seltzer is a name of popular stomach ache syrup in the United States; and as I already talked about the use of footnotes in translation, ${ }^{10}$ I used شربت معده (sharbate me'deh). One of the visitors by the name of Shohreh comments on this equivalent and suggests the use of قرص معده (qorșe me'de). She argues that "Alka Seltzer is not a stomach ache syrup, it is a soluble tablet like Vitamin C tablets in Iran which is used to cure the problems of the stomach and headache, and it is not in the form of syrup. As you are living in Iran and have more contact with Farsi speakers' every day language, you are in a better situation to suggest a proper equivalent. But here people usually have it after drinking as a hangover cure or as a cure for their stomach problems."

This comment shows one of the advantages of using an on-line translation workshop. The translator receives a comment from someone who is familiar with the issue or has had personal contact with it. As Shohreh suggests correctly Alka Seltzer is not a syrup and it is a tablet. Therefore this interaction through web log between the translator and his web log's visitor helps him to record the correct translation in his final translation manuscript.

1.2 Shed been amazed by the energy people put into the surveys.

$$
\begin{aligned}
& \text { كلمهى مورد نظرم energy است كه در وهلهى اول شايد انرزي يا حتى نيرو ترجمهاش كنيم كه هيج كدام }
\end{aligned}
$$

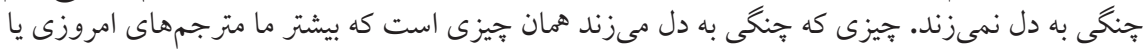

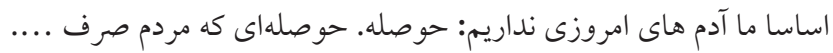

10. He argues in one of his posts that it is better not to have many footnotes in his translation. In this way, he hopes that the Iranian readers enjoy the reading just like the English readers of the book. 
(kalameye mūrede naz̧aram energi āst ke dar vahleyeh avval shāyad energi yā hattā nirow tarjomeash konim ke hich kodām changy be del nemizanad. chizi ke changī be del nemizanad hamān chizi ast ke bishtare ma motarjemhāye emrūzi yā aslan mā ādamhāye emrūzi nadārim: hūseleh. hūselehyi ke mardom sarfe....)

Mohsen Azarm:

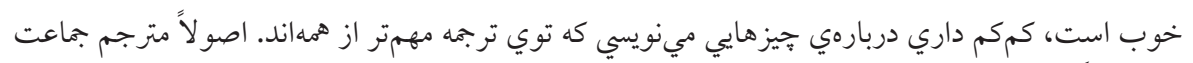

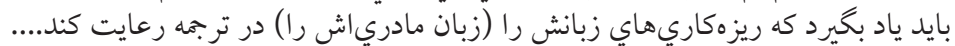
(Khūb āst, kam kam dāri darbāreye chizhāyi minevisi ke tūye tarjomeh āz hameh mohem tarand. ūsulan motarjem jema’at bāyad yād begirad ke rizekarihaye zabānash ra, zabāne madariyash ra, dar tarjomeh re’ayat konad.)

A lady:

( hūseleh rā sarf mikonand? Yā be kharj midan?)

$$
\text { حوصله رو صرف مي كنند؟ يا به خرج ميدن؟ }
$$

Maryam:

$$
\text { يافتن كلمات مناسب و بازي با وازه ها لذت عميقي به من مي دهد. وبلاكَتان را به همين دليل مي خوانم و }
$$

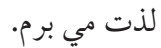

(yāftane kalamate monāseb va bazi ba vazhehha lez̄atte amiqi be man mid̄ahad. Veblāgetan ra be hamin dalil mikhvānam va lez̄aat mibaram.)

In this post, Haghighat argues that the word "energy, at the first sight, recalls the Persian equivalent of نرزي (energi) and نيرو (nirow); but none of these words is exactly right, and what most present translators or human beings lack is patience." Therefore he chooses the Persian equivalent حوصله (hūseleh), which means patience in English. Mohsen Azarm, an Iranian writer and journalist visited the web $\log$ and upon reading this post, encouraged his initiatives in the translation: "now I see that you are writing about more serious problems in translation. Basically, the translator is required to observe his/her mother's linguistic niceties". Another visitors by the name of "a lady", wonders what Persian word should follow the Persian noun حوصله (hüseleh). And finally another visitor believes that "the search and the game of finding the proper equivalent gives her deep pleasure".

1.3 She weeps freely, knowing that she can't afford to buy it.

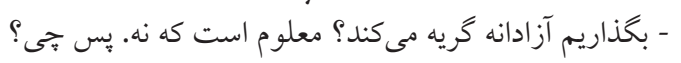

(begoz̄arim azadaneh geryeh mikownad? Ma’lūm ast keh nah. Pas chi?)

Azadeh:

$$
\text { اصطلاح از همه مناسبتره، به ذهنم رسيد ولى كفتم شايد نخوره. حالا هر جى فكر مى كنم مىبينم اين }
$$


(bā abre bahār bishtar movafeqam, be żehnam resid vali goftam shayad nakhūreh. Hālā har chi fekr mikonam mibinam in eștelah az hameh monasebtareh.)

Sara:

(misheh goft: hamin tor ashk mirikht.)

$$
\text { ميشه گفت: همين طور اشك مى ريخت. }
$$

Amirhosein:

... با دونستن اينكه استطاعت مالى خريدن اونو نداره، بدون اميدى به داشتش گريه ميكنه. (bā dūnastane inkeh esteța'ate māliye kharideh ūnū nadāreh, beduneh omidi be dāshtanesh geryeh mikoneh.)

Haghighat in this post argues that the literal translation of "she weeps freely" is not proper in Farsi, and asks his visitors to share their equivalents. Azadeh suggests (abreh bahar), which Farsi speakers use when they want to describe a continuous weeping which is very close in meaning to what Sara refers to in her post as (همين طور اشك مى ريخت hamin tor ashk mirikht). Amirhosein, another visitor, offers a rather long comment on "weeping freely" and his interpretation of it and suggests the use of

$$
\text { با دونستن اينكه استطاعت مالى خريدن اونو نداره، بدون اميدى به داشتنش گريه ميكنه. }
$$

1.4

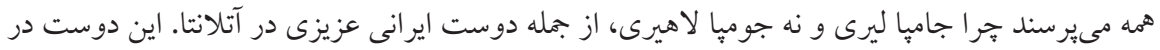

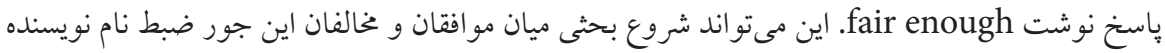

$$
\begin{aligned}
& \text { باشد، و شروع بحث مفصلترى دربارهى تلفظ اعلام. }
\end{aligned}
$$

(hameh miporsand cherā jāmpā liri va nah jompā lāhiri, az jomleh dusteh iraniyi azizi dar Atlāntā. In dvūst dar pāsokh nevesht fair enough. In mitavānad shoroeh bahsi miyāneh movāfeqān va mokhālefāne in jor zabte nāme nevisandeh bāshad, va shorueh bahseh mofașșaltari darbareye talaffoz̄eh a'lam.)

Setare:

$$
\text { لاهيرى بيشتر رنخ هندى دارد اما ليرى جنان رنغى ندارد. }
$$

(Lāhiri bishtar range hendi dārad āmma liri chenān rangi nādarād.)

Sudeh:

$$
\text { من ميخم هر طور كه خودش تلفظ مى كنه درست ترينه. }
$$

(man migam har tor keh khodash talaffoz mikoneh, dorostarineh.)

The pronunciation of Jhumpa Lahiri's name for both English and Farsi speakers poses some problems. Haghighat considers this problem in one of his posts and 
asks the visitors what they think. An Iranian visitor, a resident of Atlanta, asks him why he has preferred جاميا ليرى (jāmpa liri). Haghighat replies:

Soon I will talk about the pronunciation in detail, but now let me just mention that as you should know, Americans pronounce Lahiri as Lairi; and in an interview, she has talked about her childhood when her classmates teased her by repeating Jhumpa jump. Besides, even in India, the pronunciation differs from each province to another. Even an Indian guy told me they pronounce it as Liri.

Haghighat's replv seems to be satisfactorv for this visitor as he describes it as "fair enough". However, this "discussion provides a platform for opening an exhaustive discussion on recording of proper names" Haghighat argues. Later when Haghighat interviews Jhumpa Lahiri, he realizes that the correct pronunciation of her name in Persian is جوميا لاهيرى (jompā lāhiri) but it is too late to correct it in his translation, because the book was already in the process of publication. Two other visitors also make suggestions on this matter: Setareh believes that لاهيرى (lāhiri) has an Indian flavor, while ليرى (liri) lacks such a quality. Sudeh, another visitor, argues that "the best way to know the correct pronunciation is to listen to what Lahiri calls herself". Although the correct pronunciation of the author did not find a way in the first edition, the translator applied it later in all his references.

\section{General discussions}

In our discussion so far about The Namesake's on-line translation workshop, I covered some sample examples of the issues mostly associated with the art of translation and problems of translation. However, as the web log is a kind of personal web page, the blogger has the authority to post miscellaneous topics to it and in the case of translation this may be any kind of information or topics beyond the technical problems of translation. The blogger and the visitors are free to express themselves. It is remarkable to notice that the following discussions are rarely finding their ways into traditional translation methods.

In my analysis of the Tarjomeh, I have found different kinds of comments sent by the visitors that are ranging from friendly encouragement to accounts of personal feelings of visitors. Recognizing the increasing number of visitors, Haghighat notes that an on-line group of prospective readers is forming before the publication of the book. Accordingly, he tries to provide them with more information about his translation of The Namesake and its writer.

Some of the discussions in this part are of great significance in the process of translation. As translators infrequently talk about their work and how they translate, Haghighat provides his visitors with a useful account of his work in his web log. Susan Bassnet, a theorist of translation, argues that translators "in discussing 
their work, avoid analysis of their methods and concentrate on exposing the frailties of other translators" (18). In the case of Haghighat, as I mentioned, he do talks about his methods of translation.

Here I have chosen four examples of the discussions. The first one is about Haghighat's translation methods, and is very personal indeed.

\section{A translator's self-portrait}

Haghighat in one of his posts on 22 November 2004 presents the history of his translation. The whole period lasted for 9 months, starting from November 2003 to August 2004. He writes that each of these dates reminds him of a special state of mind. He recalls those days as follows:

Once I left Tehran and went to an empty room somewhere far from Tehran, and closed the door. Of course I had my cell phone and Walkman. I had already bought some food, though later I realized that I'm not a good cook, and that's why I didn't enjoy it a lot. Once I also translated on our house balcony overlooking a highway and was sunburned. Then I continued my work in Gorgan and left my friend's house at nights.

He then goes on to discuss his personal habits in translation in the following words:

During my translation, I finished two packets of A4 papers for the first draft, and two more for the final copy. I wrote my translation in pen on one side of the paper, double spaced. I finished two big Pelikan erasers, and four or five packs of pen leads along with 200 or 300 grams of coffee and much more tea. Before the translation, I read the original text two times and in the second reading, I took notes of those equivalents that occupied my mind. I had the book copied and wrote all the notes on the copied draft. I made a duplication of my final copy and rebound the original copy in the form of two thick notebooks. I gave them to two of my learned friends to read and comment [...] during this time and between my translation, I read Ragtime, A Farewell to Arms, And When Did You Last See Your Father, The Adventures of Huckleberry Finn and The Persian Folklore Dictionary. While my translation was in the Auditing Office, I edited my translation two or three times, which got on the nerves of my publisher, proofreader and the typist. After all, I still believe that my translation of The Namesake needs more editing.

This sincerely translator-oriented perspective of how the translation process works, and what a translator's habits are, provides valuable information for translation researchers and theorists who strive for a better understanding of translation practice and how different translators translate. The close analysis of translator's personal habits in translation can provide new areas of research in translation studies that in turn may result in new translation theories and translation strategies. 
A documented censorship

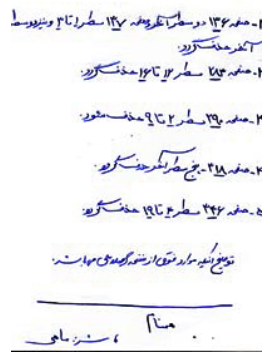

This is a picture of a piece of paper written in Persian by an official of the Auditing Office that I already talked about. Haghighat describes it as "a worn out, nameless paper without any description or reason". Although the Iranian translators are quite familiar with the governing rules of censorship in Iran, it is the first time that an Iranian translator documents it thanks to the web log. In some cases, he had to delete up to 15 lines of his translation. Most of these parts are those that are associated with the love relationship between the characters.

The news of the upcoming translation

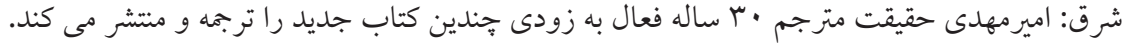

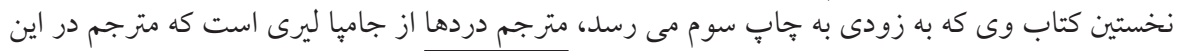

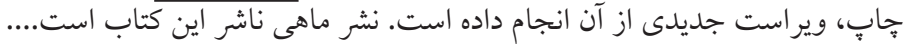

As I already stated, the web log benefits from instant access to other on-line resources through the hyperlinks. Haghighat covers all the news related to his translation of the novel that is published in Persian press. In this post, he quotes a short news story that appeared in Shargh Daily, a popular Persian daily. The daily gives background information about the novel and the translator's previous translation of The Interpreter of Maladies.

\section{The translator as a journalist}

During his translation and blogging, Haghighat established contact with Jhumpa Lahiri. He asked for an interview which later got published in Hamshahri, a popular Persian daily. In this interview, many issues are dealt with, like Lahiri's works and life, the plot and rhythm in her stories, the relationship between loneliness and literature, her favorite authors and the correct pronunciation of her name. As a good translator, according to Robinson, one "always wants to know more, always wants to have experienced more, never feels quite satisfied with the job s/he completed" (112). Haghighat's contact with the author helps him to acquire an ample 
understanding of the world of the author he is translating. This is one of the strategies that the translator can employ to improve his/ her quality of translation.

\section{The translator signs his published translation}

$$
\text { دعوت اختصاصي از خوانندكان اين وبلاكى براي حضور در مراسم جشن رونمايي همنام: نشر خشمه، فردا }
$$

The Persian translation of The Namesake is about to be published and the translator invites his web log visitors to a book signing ceremony. Usually this kind of ceremony is held for very famous writers, not for translators. It is probably for the first time in the history of translation in Iran to see a translator receiving such unprecedented attention.

\section{Discussion}

I would now like to evaluate the on-line workshop of The Namesake in the light of the examples I provided earlier in this article. As far as our translator is concerned, he did not know that what he was exercising on his web log was, indeed, the same as practicing and managing an on-line translation workshop. When I asked him if he thought of his web log as a workshop, he told me

I just see it as somewhere to share my ideas, and I have come to the conclusion that it's not of that much use. Although the idea of such a workshop seems very exciting, and even some experienced translators visit it, despite my expectation, neither they nor students attend the workshop very often. On the other hand, maybe my expectation is very high. Maybe with the low number of readers in Iran, we should not expect many audiences or visitors for such a specialized blog. ${ }^{11}$

Despite the fact that Haghighat seems to diminish the importance of his web $\log$ as an on-line translation workshop in the process of his literary translation, he should observe the fact that, at least, he practiced it for the first time in Iran. Now the literary translators have this unique opportunity to apply the web log in their work and examine the degree of success in producing a better translation. If we consider translation as "an intelligent activity, requiring creative problem-solving in novel textual, social, and cultural condition" (Robinson 5), and the translators, as human beings who "learn words and phrases, styles and tones and registers, linguistic and cultural strategies while translating, while interpreting, while reading a book or surfing the Internet"( 57), and as in our case, using a web log in literary translation as a workshop, we come to the conclusion that the web logs can be thoroughly applied, provided that the translator optimizes the quality of his/her web log or workshop.

11. Haghighat, A. M. “Re: ques.” E-mail to E. Haddadian Moghaddam. 23 Oct. 2005. 
But how can translators, as some of the busiest social human beings, who according to Robinson, "depend for their livelihood on their social connection with other human beings" (192), make the best use of web logs in their translation? And how can the teachers of translation who are accustomed to the formal and spiritless environment of translation classes, get down to business and learn to apply web logs?

First of all, it is the responsibility of the literary translators and translation teachers to acknowledge the growing importance of new technologies available for them; and secondly, to make informed decisions for the effective use of translation technology, which Austermühl argues "starts from the translator's position" (11). He believes that the translator "has to determine what type of translation technologies are needed at what stage in the translation process in order to optimize his or her professionally performance" (11). If we divide the process of translation into three stages of pre-translation, translation and post-translation, the web logs are the best tools in the first two stages.

For literary translation, the web log has many advantages as we reviewed it in this paper. It can act as a mediator between the translator and his/her potential readers. Every literary translator can create the web log in a few steps and manage it very easily; then inform others of the decision and keep them informed of his/her translation activities. When the translator has adopted a new literary translation, $\mathrm{h} / \mathrm{she}$ can share the experiences, the problems and seek advice. And $\mathrm{h} / \mathrm{she}$ is able to create a virtual, universal world around the translation which is much bigger than his/her small world. In this way, the literary translator faces a unique landscape which "is not mapped by conventional geographies" (Bush 127). Furthermore, the literary translator can establish contact with a living author, whose book is going to be translated. Bush calls this one of the "collaborative possibilities" for literary translators in translation (129). This possibility connects the literary translator to the original writer, and in the light of this collaboration, the chance of producing an acceptable translation in the target language is double.

Care should be taken while managing a web log as an on-line translation workshop. Not all visitors enjoy the same level of translation knowledge as in formal translation classes. Their degree and scope of interest in translation varies from person to person. It can be assumed that the majority of the visitors are at least interested in literary translation. By analyzing the received feedbacks and comments, the translator can manage the web log and direct the discussion towards translation. In the light of the discussions in this paper, the best case for using a web log as an on-line translation workshop is the simultaneous use of the web log with the translation. While the translator adopts a new work, $\mathrm{h} / \mathrm{she}$ should start his/her web log, and define some rules for the visitors to observe 
while commenting on the posts. Optimization of a web log as an on-line translation workshop needs more practical applications. And as it is still a very new phenomenon, it needs more time and research to be done. It is obvious that the disadvantages of using a web log in literary translation, apart from the ones I mentioned in this paper, will be clarified later thanks to more applications of web logs in translation.

\section{References}

Alavi, Nasrin. 2005. We Are Iran: The Persian Blogs. New York: Soft Skull Press. 384 pp.

Austermühl, Frank. 2001. Electronic Tools for Translators. Manchester: St. Jerome. 192 pp.

Baker, Mona, ed. 2001. Routledge Encyclopedia of Translation Studies. London: Routledge. xvii $+654 \mathrm{pp}$.

Bassnett, Susan. 2002. Translation Studies. 3rd ed. London: Routledge. 192 pp.

Gentzler, Edwin. 2001. Contemporary Translation Studies. Rev. ed. Clevedon: Multilingual Matters. $232 \mathrm{pp}$.

Haddadian Moghaddam, Esmaeil. 2005. “Blogging in Iran”. The Reader 22-23.

Haghighat, Amir Mehdi. 1384. Hamnam. Tehran: Nashreh Mahi. 360 pp.

Hung, Eva, ed. 2002. Teaching Translation and Interpreting. Vol. 4: Building Bridges. Amsterdam: John Benjamins. 255 pp.

Kipen, David. 2003. “An Indian immigrant's son who is neither here nor there”. Chronicle, 14 September.

Lahiri, Jhumpa. 2005. The Namesake. London: Harper Perennial. 291 pp.

Macintyre, Ben. 2004. "Welcome to the New Tom Paines". Times on-line. http://www.timesonline.co.uk/article/0,,482-1356091,00.html. 10 Nov. 2005.

Munday, Jeremy. 2001. Introducing Translation Studies: Theories and Application. London: Routledge. $240 \mathrm{pp}$.

Newton, John, ed. 1992. Computers in Translation: A Practical Approach. London: Routledge. $260 \mathrm{pp}$.

Persianblog. http://www.persianblog.ir. 15 Nov. 2005.

Posteguillo, Santiago et al. eds. 2003. Internet in Linguistics, Translation and Literary Studies. Publications de la Universitat Jaime I, D. L. 223-239.

Robinson, Douglas. 1998. Becoming a Translator. London: Routledge. 368 pp.

Tarjomeh. Haghighat, Amir Mehdi. October, November 2005. http://www.amirmehdi.com/ blog.

Technorati. http://www.technorati.com/about/ 13 Nov. 2005.

Toury, Gideon. 1995. Descriptive Translation Studies. Amsterdam: John Benjamins. viii + 311 pp. Translation and Intercultural Studies. http://www.translatornotes.blogspot.com.

Venuti, Lawrence, ed. 1992. The Translation Studies Reader. London: Routledge. 539 pp.

Wikipedia. http://en.wikipedia.org/wiki/Blogosphere. 15 Nov. 2005. 


\begin{abstract}
Translation and literary translation in particular no longer can be seen as a static activity. In Austermühl's words, the antiquated image of a lone translator, armed only with a pencil or typewriter and surrounded by dusty books, is no longer realistic. The translators are now learning to apply the new communication technologies like Internet in their work. The web log as a recent phenomenon in the cyber world can be applied in literary translation. However, it has been overlooked in translation studies, partly, in the author's opinion, because of its novelty but to a large extent because of its popularity as a platform or a personal diary for the novice bloggers, the authors of the web logs.

In this article, the application of a web log by an Iranian literary translator in his Persian translation of Jhumpa Lahiri's The Namesake is examined. By providing examples of the discussions between the translator and his visitors (readers), and by incorporating the web log in a model of translation studies, the Holmes-Toury map of translation studies, he tries to pinpoint the advantages of web log in literary translation in respect to its application as an online translation workshop. The author argues that the web log can be thoroughly applied in literary translation provided that the translator optimizes the quality of his web log or workshop by acknowledging the growing importance of new technologies available for him; and making informed decisions for the effective use of translation technology. What distinguishes the online translation workshop from its traditional one is its round-the-clock opening, facilitated interaction with the translator, absence of any formal setting and formality and instant access to available sources in Internet.

The application of weblogs as an online workshop has some advantages for the literary translator: acting as a mediator between the translator and his potential readers; sharing the experiences, problems and seeking advice; and, creating a virtual, universal world around the translation which is bigger than his/her small, personal world.
\end{abstract}

\title{
Résumé
}

On ne peut plus considérer la traduction et la traduction littéraire, en particulier, comme une activité statique. Comme le dit Austermuhl, la vieille image du traducteur solitaire, armé de son seul crayon ou d'une machine à écrire et entouré de livres poussiéreux, n’est plus réaliste. Aujourd'hui, les traducteurs apprennent à utiliser dans leur travail les nouvelles technologies de communication, comme l'Internet. Le blog, un phénomène récent dans le cybermonde, peut s'appliquer à la traduction littéraire. Toutefois, il a été négligé par la traductologie, en partie, estime l'auteur, en raison de sa nouveauté, mais aussi, dans une large mesure, en raison de sa popularité en tant que plate-forme ou journal personnel des 'blogueurs' novices, les auteurs de blogs.

Dans cet article, nous examinons l'utilisation d'un blog par un traducteur littéraire iranien, dans sa traduction en perse de The Namesake de Jhumpa Lahiri. En citant des exemples de discussions entre le traducteur et ses visiteurs (lecteurs) et en incorporant le blog dans un modèle de traductologie, le graphique Holmes/Toury des études de traduction, il cherche à mettre le doigt sur les avantages d'un blog pour la traduction littéraire, en ce qui concerne son utilisation comme atelier de traduction en ligne. Lauteur avance que le blog peut être parfaitement utilisé en traduction littéraire, à condition que le traducteur optimise la qualité de son blog ou atelier, en reconnaissant l'importance croissante des nouvelles technologies dont il dispose et en 
prenant des décisions bien informées afin d'utiliser efficacement la technologie de la traduction. Ce qui distingue un atelier de traduction en ligne d'un atelier traditionnel est son accessibilité 24 heures sur 24, une interaction plus aisée avec le traducteur, l'absence de toute structure formelle et de tout formalisme et l'accès instantané à des sources disponibles sur l'Internet.

L'utilisation d'un blog comme atelier en ligne présente certains avantages pour le traducteur littéraire : il joue un rôle de médiateur entre le traducteur et ses lecteurs potentiels. Il y a un partage d'expériences et de problèmes et une demande de conseils. Et il crée autour de la traduction, un monde virtuel, universel, qui dépasse le petit monde personnel.

\section{About the Author}

Esmaeil Haddadian Moghaddam is a PhD student of Translation and Intercultural Studies at Universitat Rovira i Virgili in Spain. He received his Master degree in English literature from university college Dalarna in Sweden in 2006. He is an Iranian published translator, journalist and blogger on translation and a contributor to Motarjem (Iranian Journal of Translation). In 2004, he received the best translation prize for translation of the children books in Iran. His main areas of interest are literary translation, sociology of translation, translation technologies, and the history of literary translation in Iran.

Address: Norra Järnvägsgatan 20: 8, 79135 Falun, Sweden.

E-mail: ehaddadiyan@yahoo.com.

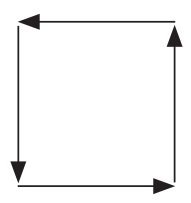

Vierteljahresschrift für die Übersetzungspraxis

Bulletin trimestriel sur la pratique de la traduction

Rivista trimestrale par la traduzione pratica

\section{Quarterly on the practice of translation}

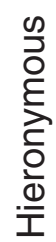

The official journal of the

Swiss Association of Translators,

Terminologists and Interpreters

Subscriptions and advertisements:

ASTTI, Postgasse 17, CH-3011 Bern

Telefax (+41 31) 3138899 www.astti.ch 
Copyright of Babel is the property of John Benjamins Publishing $C_{0}$. and its content may not be copied or emailed to multiple sites or posted to a listserv without the copyright holder's express written permission. However, users may print, download, or email articles for individual use. 